\title{
BLDE (Deemed to be University) central library as an ICT HUB of resources \& services
}

\author{
Suvarna S Hiremath ${ }^{1}$, Shivakumar Acharya ${ }^{2 *}$, Somashekar Lalasanji ${ }^{3}$ \\ ${ }^{1}$ Senior Librarian, ${ }^{2}$ Assistant Librarian, ${ }^{3}$ Senior Assistant Librarian, BLDE (Deemed to be University) central library, Vijayapur, \\ Karnataka, India \\ *Corresponding Author: Shivakumar Acharya \\ Email: suvarnah1965@gmail.com
}

\begin{abstract}
During the second half of the twentieth century, many researchers and practitioners have claimed that libraries in academic institutions must make dramatic changes or face the possibility of being marginalized. In a study of innovation in academic libraries, Clayton stated that "innovation is no longer an option but a necessity". Libraries and information centers are playing an important role in keeping well informed these organizations and the society as whole, with most up-to-date information. Therefore services provided by such information centers are very significant. Also in this IT era, the role of the libraries and information centers has been changed drastically. They have to deal with all types of novel technology. They have to be familiar with the new and universal trends in handling the information and providing prompt as well as accurate services. In field of higher education, the Academic Libraries have vital role to play. The Central Library of BLDE (Deemed to be University) (Medical),Vijayapur is a leading medical library in Karnataka, shouldering its responsibility towards catering the information requirements of upcoming doctors in the field of medicine, surgery, pediatrics, ENT,OBG etc.. In my paper, taking BLDE (Deemed to be University)'s Central Library as a case study, an attempt has been made to highlight the innovative practices adopted in the mode of delivering the library services for the Research, Consultancy and Innovative practices adopted to satisfy the ever changing needs of the users of the modern ICT era.
\end{abstract}

Keywords: Innovation Practices, BLDE (Deemed to be University), Central Library, Higher education.

\section{Introduction}

"University and Colleges form the important and integral part of Higher education and libraries in university are the primary source for learning and research process. The university library is a connecting link between teaching and learning as well as place which supplements its resources what is beyond scope of class room. University libraries play an important role in the educational history of Students, Researcher, as well as the faculty members. It serves the students, Research Scholars and faculty by providing specific information. But how far the university libraries are successful in implementing their goals into its reality is a big question. There must be some agency to have a proper vigilance on the functioning of university libraries and also to suggest certain measures to rectify the emerging needs, and for this purpose NAAC was established for assessing the quality of education and maintenance of the institutions." 1

\section{BLDE (Deemed to be University) at Vijayapura}

BLDE (Deemed to be University) is one amongst the reputed Universities in Karnataka, providing education in various Medical Courses. Housed in a sprawling campus at Vijayapur (former Bijapur) in Karnataka, It was declared a University under sec 3 of the UGC Act 1956 and approved by Ministry of Human Resource development. It has been established under BLDE Association, a renowned educational Society, running more than 75 institutions in the state.

BLDE (Deemed to be University) was established as a Deemed University under sec 3 of the UGC Act 1956. The Constituent College of the University, Sri. B.M. Patil Medical College Hospital \& Research Center, Vijayapur, was established in the year 1986 by BLDE Association Bijapur (Bijapur Liberal Development Education Association)
BLDE (Deemed to be University) has the necessary infrastructure and equipments for imparting Medical Education. It houses the college departments, central Library and residential quarters in various blocks spread across a huge campus. There are separate hostels for boys, girls, NRI students and PG students. The university Library has enviable collection of books, journals, E-books, E-journals, back volumes etc which are available for faculty and students for reference. Besides all these amenities, the University maintains state -of- the- art laboratories \& library for providing teaching and research facilities.

\section{BLDE (Deemed to be University) Central Library}

Central Library established in the year 1986. It serves as a resource center for health science information. Also serves as a gateway to the electronic and print biomedical information. Library's primary clienteles are the University's Students, Faculty, Research Scholars, Staff and outside health science professionals. Apart from this, to provide ready references at work place, 21 departmental libraries were established.

Central Library developed a set of innovative practices under the following 4 major areas:

\section{Management of Library \& Information Services Collection and Development. Service and Facilities for Users. Use of Technology.}

\section{Management of Library \& Information Services}

In universities and colleges, the library system normally consists of a central library and branch/department libraries. The large campus environment often defines the use of the library in terms of the strength, size of the text and research collection and working hours, easy and speed access of the 
collection and services. The central library supports the general information requirements of the patrons whereas the department libraries cater to the specific subject needs of the users, both for study and research. With regarding these following are the practices of the BLDE (Deemed to be University)'s Central Library:

1. Number of day the library is kept open: All the sections of the Central Library are kept open on all the 365 days of a year.

2. Working Hours: General working hours of the Medical college is between 10.00 am to $5.30 \mathrm{pm}$, but the Central Library is kept open from 8:00 AM to 10:00 PM on all the 365 days in a year, so that the users can get the opportunity to use the library without disturbance to their academic schedules.

3. Library Advisory Committee: The Central Library has an active Library Advisory Committee, which consists of Vice Chancellor of the University as Chairperson, Heads of the Departments, student representatives as members and the Chief Librarian as the Member Secretary. The committee meets once in quarterly to discuss the developmental activities of the library.

4. Manpower Development: Qualification and experience of the librarian and the library staff are on par with that of the academic staff and as per the norms of UGC/MCI etc. for guaranteeing a professional approach in delivering information services. The Central library Staff consists of One Chief Librarian, Two Deputy/Senior Librarians, Three Assistant Librarians, One FDA, One SDA, One Clerk cum Typist, One Xerox machine Operator, Six Attenders/Peons, and Three Sweepers/Cleaners.

5. Performance Evaluation of the Library: Once in a year at a regular intervals performance evaluation of the library services \& facilities is carried out from both the students \& faculty members of the university to enhance the quality and its sustenance by distributing questionnaire to both the patrons to get their feedback.

\section{Collection and Development}

The Central library provides varied, authoritative and up-todate resources that support its mission and the needs of its users. Moreover, resources are in a variety of formats, including print, electronic and other media. The quantity of resources is maintained as prescribed by the Medical Council of India (MCI) requirements. The resources are in the form of text books, reference books, current journals which include national, international and peer reviewed journals, back volumes, e-resources such as full text, abstracts, CDs/DVDs, AV materials, etc. The Library maintains a special collection of national and international agencies (WHO, UGC, DST etc.). Collection currency and strength is maintained through judicious weeding-out

\begin{tabular}{|l|c|}
\hline \multicolumn{1}{|c|}{ Particulars } & Total \\
\hline Books & 18251 \\
\hline Back Volumes of Journals & 7378 \\
\hline National Journals & 76 \\
\hline
\end{tabular}

\begin{tabular}{|l|c|}
\hline International Journals & 76 \\
\hline Dissertations & 451 \\
\hline News Papers & 14 \\
\hline Magazines & 13 \\
\hline
\end{tabular}

\begin{tabular}{|l|c|}
\hline Particulars & Total \\
\hline HELINET E Database-Books & 3835 \\
\hline HELINET E-Journals & 295 \\
\cline { 1 - 2 } $\begin{array}{l}\text { PROQUEST Health and Medical complete } \\
\text { Database }\end{array}$ & \\
\cline { 1 - 2 } $\begin{array}{l}\text { PROQUEST Nursing and Allied Health } \\
\text { source Database }\end{array}$ & 181 \\
\cline { 1 - 2 } E - Books (Print + online) & 128 \\
\hline E- Journals (Print + online) & 118 \\
\hline Audio Cassettes & 52 \\
\hline Video Cassettes & 410 \\
\hline CD/ DVDs & 650 \\
\hline FACULTY PUBLICATIONS & 159 \\
\hline DISSERTATIONS & \\
\hline
\end{tabular}

\section{Service and Facilities for Users}

The Central Library offers a wide range of services including the basic \& routine library activities like cataloguing, check ins - checkouts, renewal of books \& journals and inventory of users (entry \& exit), OPAC etc. are being handled through a good library management software called NewGenLib ( Helium Version NGL Core Engine 3.1.2) and it is an open source by nature and the source codes can be customized according to requirement of the particular library and we in our Central Library of BLDE (Deemed to be University), Vijayapur are using all the modules of the NGL to their best.

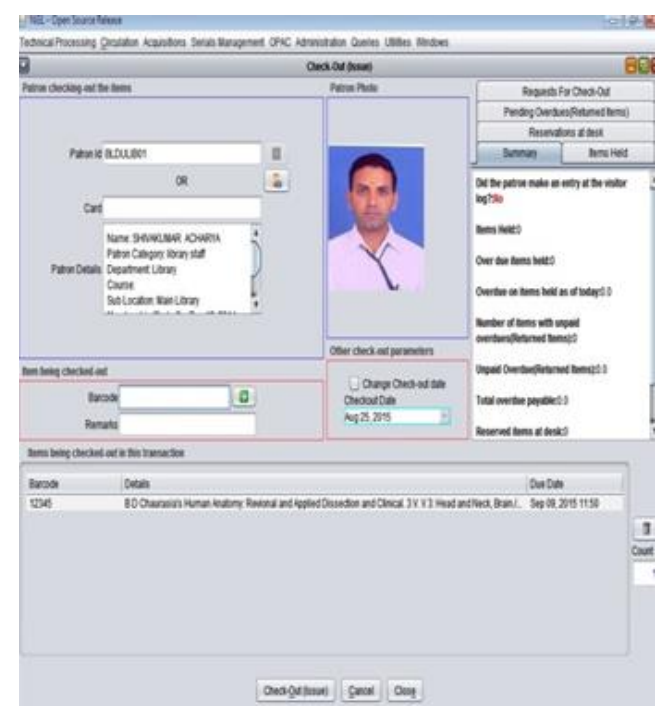

Fig. 1: Circulation Module in NGL 


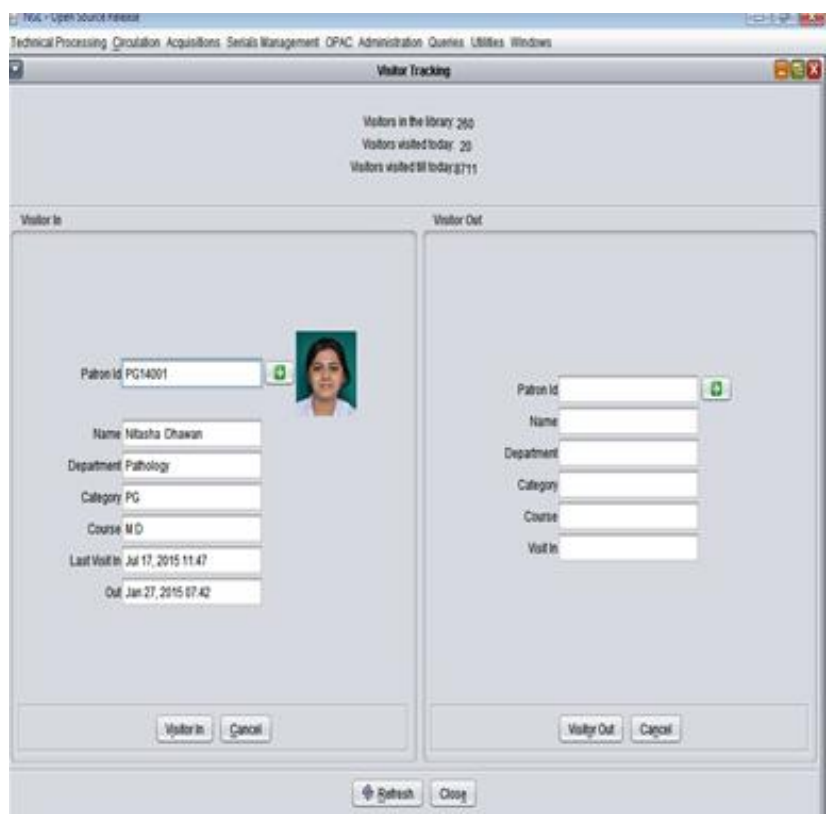

Fig. 2: Inventory of Users in NGL

Library is automated with NGL 3.1.2 library management open source software. "The main aim of the collection development is to make available all types of important reading material, i.e. General books, reference books, text books, reports, patents, ,theses, Dissertations, serials, journals, non-book material resources etc to support learning, teaching and research pursuits of readers of the college" ${ }^{6}$ by the active University Library Committee.

\section{Services and facility for users}

All types of Library services are providing for users in BLDE (Deemed to be University) Central library. Few best practices in this area are as follows:

1. Current Awareness Services (CAS)

2. Literature Search through database and internet resources

3. Document Delivery Service (DDS)

4. Reprographic Service

5. Referral Service

6. News Paper clipping Service.

7. E-mail alert Service for the circulation related transactions (issue, return, renewal, reminder, new arrivals of library reading materials.)

8. RFID enabled circulation and stock check.

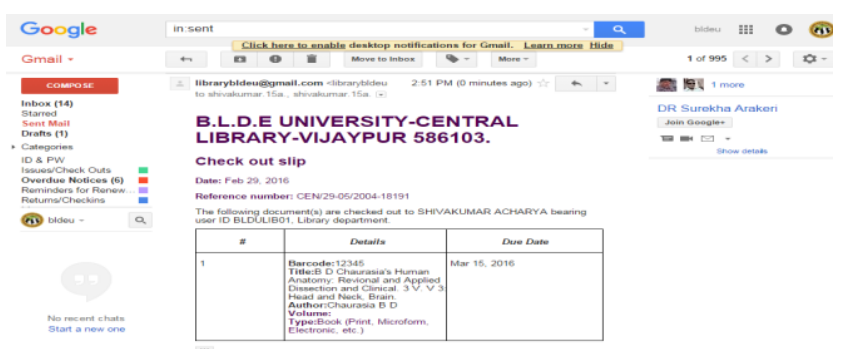

Fig. 3: Automatic E-mail alert for issue/checkout of a book
1. SMS alert Service

2. Electronic Resource Search through Internet.

3. Repository of old question papers (Soft copy) maintained through D Space

4. Repository of research publication published by the faculty maintained through D Space

5. Plagiarism checking of the articles, theses \& dissertation reports by using a very good international standards Anti Plagiarism software called 'TURNITIN'

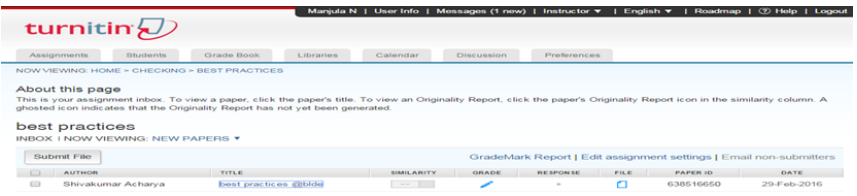

Fig. 4: Checking the Plagiarism of the article using 'turnitin'

Repository of Ph.D thesis submitted to BLDE (Deemed to be University) Central Library by the Doctoral students in Shodhganga: a reservoir of Indian theses @ INFLIBNET.

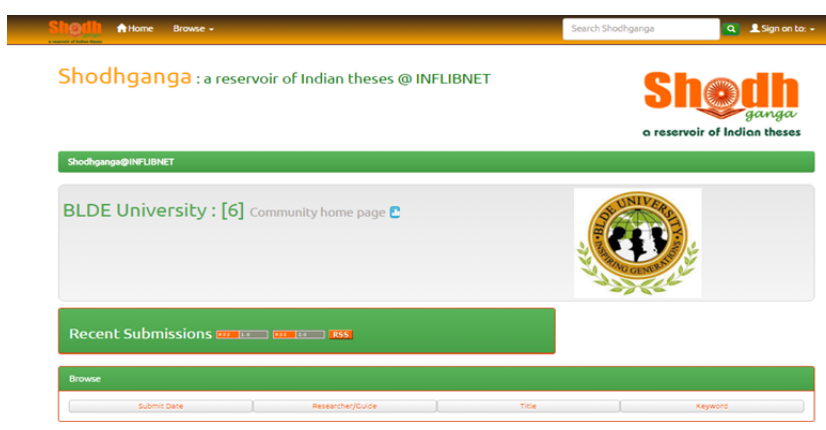

Fig. 5: Repository of six Ph.D theses in Shodhganga

\section{Facilities for Users:}

1. Wi-Fi Facility available in the Library.

2. OPAC (Online Public Access Catalogue).

3. Facility for Video Conference.

4. Reading Rooms with air conditioned provided for students.

5. Book Bank Facility available for SC/ ST Students.

6. Purified Drinking water, separate Rest Rooms for ladies and gents in each floor.

7. Mini Cafeteria in the Library

8. Separate Ramp provided for physically challenged.

9. Visitor Tracking facility (registering of Entry / Exit of Users in the computer system)

10. Other facilities: CD Writer/ Printers, Scanning of documents available for users.

\section{Use of Technology in the Central Library:}

Central Library of BLDE (Deemed to be University) uses the state of the art technology for its library operations, services $\&$ facilities as follows: 


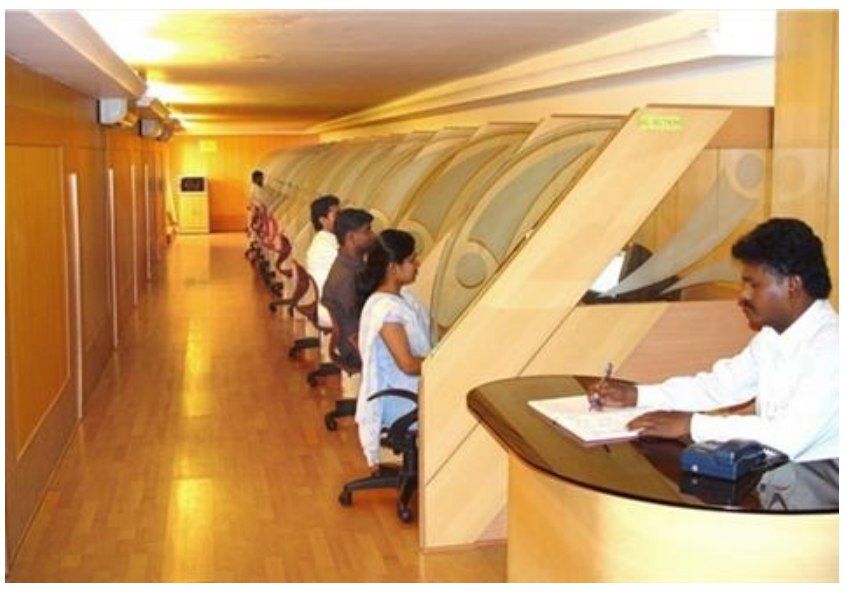

The students and faculties are provided 50 computer systems with 50 mbps bandwidth Internet facility to full fill their educational needs like "filling up e-scholarship forms, use HELINET \& Proquest Consortia journals, e-books, check emails, get information from govt. websites, fill online job application forms and check results online, etc and faculty get information about the research made in their concerned subjects as well as to take help from internet sources in their teaching learning methods including reading materials." 6

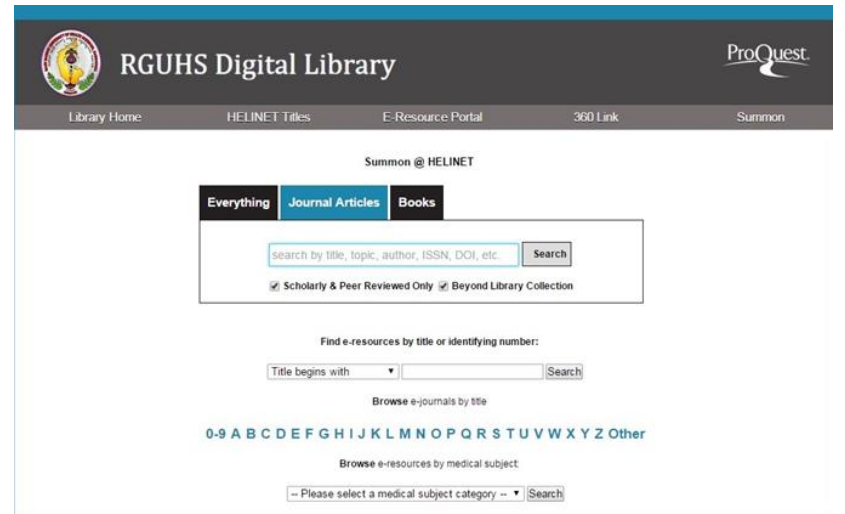

Fig. 6: HELINET webpage @ BLDE (Deemed to be University) Central Library

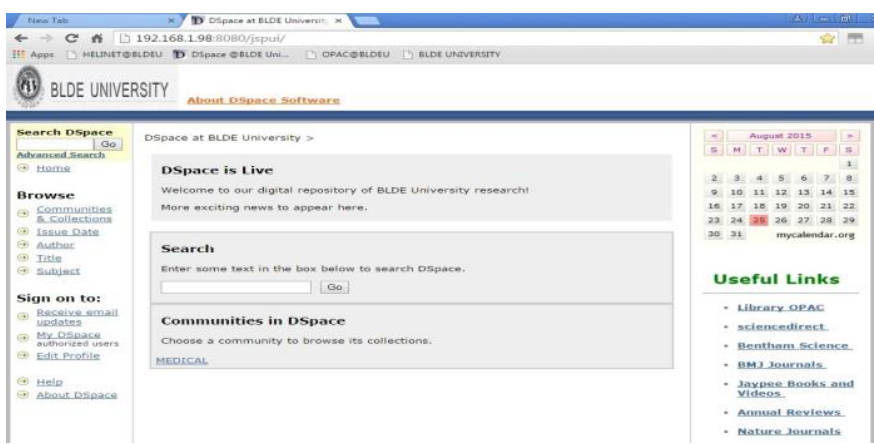

Fig. 7: DSpace @ BLDE (Deemed to be University) Central Library

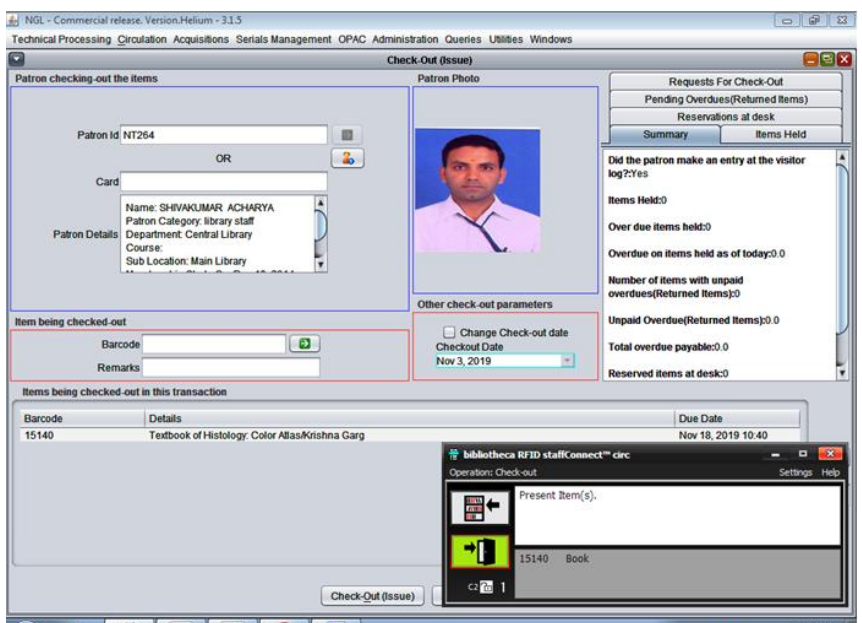

(9) 1 留

Fig. 8: RFID Enabled Circulation@ @ BLDE (Deemed to be University) Central Library

\section{Conclusion}

Now-a-days Libraries are required by their institutions not only to demonstrate return on investment but also to provide reliable statistics and other evidence based data. As such understanding what we mean when we use terms such as 'best practices' and increasing the rigor of our analysis is critical to our future. At the same time, the accreditation activity is gaining momentum in our country as people and educational institutions have come to realize that quality enhancement is essential for the institutions and the country. In the process of institutional accreditation, libraries have a crucial role. The services of the libraries have been expanding as they contribute significantly to the learning process, particularly the E-Learning process.

In the process of achieving best practices in the libraries, we should recognize the danger in assuming that there is some yardstick for libraries' practice. A best practice might stifle critical problem and creativity and ironically bring about inferior results. It may reduce us to merely adopting a practice whose results are not replicable in our own institutions. This is not suggesting, however, that we abandon our search for best practices. Instead, it is to approach with caution that which we conclude is 'best'.

\section{Source of Funding}

None.

\section{Conflict of Interest}

None.

\section{References}

1. http://www.abc-clio.com/ODLIS/odlis_b.aspx Retrieved on 20.08.2015

2. Mahesh D. Horakeri, Suresh Jange and B.S. Malwad (Eds.) (2015). International Conference on Paradigms of Digital Library, E-resources, Open access and Information Media Literacy.October, 2015. ISBN 978-81-924533-7-8.

3. NAAC. Best Practices in Library and Information Services. (Website) Library and Information Services: Case Presentations. NAAC, 2006. 
4. Reitz, J. M. (2004). ODLIS Online Dictionary for Library and Information Science. Retrieved on 20.08.2015

5. Siraj Nissa Begum, S. (2003) Total Quality Management in the Academic Library. Library Philosophy and Practice. 5, 2(Spring 2003) 1-3. 8.

6. http://eprints.rclis.org/
How to cite: Hiremath SS, Acharya S, Lalasanji S. BLDE (Deemed to be University) central library as an ICT HUB of resources \& services. IP Indian J Libr Sci Inf Techno 2020;5(1):34-8. 